\title{
Evolução e cultura
}

\section{Evolution and culture}

José Augusto Drummond, Ph. D.

Pesquisador associado, Centro de Desenvolvimento Sustentável

SQN 304 bloco D apto. 507

70736-040 Brasília - DF Brasil

jaldrummond@uol.com.br

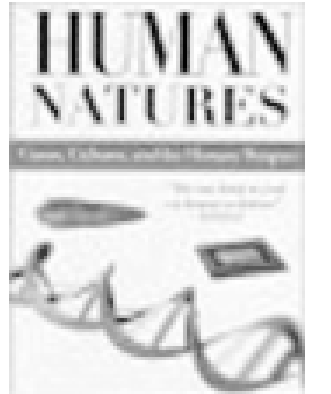

Paul It. Phrtich

Paul Ehrlich

Human natures -

genes, cultures and the buman prospect

Nova York, Penguin,

Notas, bibliografia, índice remissivo, 2002, 531p.
S e você é um cientista social que não admite que as palavras $\mathcal{S}$ 'evolução' e 'cultura' habitem a mesma frase — como fiz de propósito no título acima -, então não leia este provocativo livro de Paul Ehrlich. Mas se você é um cientista natural que acha que a genética explica sem maiores dificuldades todos os aspectos do comportamento humano, o conselho é o mesmo: não leia este livro. Ambos os tipos de leitores ficarão desconcertados e correrão o sério perigo de mudarem suas opiniões.

Paul Ehrlich tem autoridade para escrever um texto como esse, capaz de abalar as convicções dos dois lados da polêmica questão das relações entre a evolução biológica e a cultura humana. Biólogo, professor de estudos populacionais e de ciências biológicas da Universidade de Stanford California (EUA), ele é nada menos que um dos inventores da questão ambiental contemporânea. Escritor prolífico, é autor e co-autor de dezenas de artigos e livros, entre os quais figuram pelo menos dois clássicos da moderna literatura socioambiental das décadas de 1960 e 1970 - The population bomb e extinction: the causes and consequences of the disappearance of species - , que colocaram os temas da superpopulação e da extinção de espécies na pauta ambiental planetária. Ehrlich resumiu boa parte de suas próprias pesquisas biológicas e ambientais, em combinação com uma excelente exposição sobre os fundamentos da ecologia, num belo livro de divulgação científica traduzido para o português ( $O$ mecanismo da natureza, Campus). Foi também um dos primeiros cientistas a se empenhar publicamente na proteção da biodiversidade e na promoção do princípio de sustentabilidade ambiental das atividades humanas.

Durante muito tempo Ehrlich teve escassa aceitação entre ambientalistas dos países pobres em virtude de suas posições — consideradas neo-malthusianas - a respeito dos efeitos ambientais do crescimento populacional. No entanto, há muito tempo ele absorveu as críticas e reconheceu a importância dos altos padrões de vida das populações dos países ricos para a destruição ambiental em escala planetária. Considerado por muitos colegas cientistas excessivamente catastrofista e polêmico, Ehrlich exerce grande influência nos meios científicos e em organizações ambientalistas, graças a sua disposição de enfrentar muitas questões espinhosas do mundo moderno.

É precisamente o que faz neste livro, ao investigar o estado do conhecimento (e as suas conseqüências éticas ou filosóficas) sobre os limites e superposições entre o que é 'natural' e o que é 'cultural' nos seres humanos, do ponto de vista da teoria evolucionista darwiniana. Partindo de uma distinção radical entre heranças genéticas e heranças culturais, as posições de Ehrlich decepcionarão 
os dois 'partidos' que citei no primeiro parágrafo. Serão mais 'deglutíveis' do que esperaria o cientista social aferrado ao pressuposto da autonomia da cultura, e serão mais 'tímidas' do que desejaria um entusiasta da genética comportamental. Ehrlich se desvela em mostrar o 'dedo' da evolução biológica em muitos aspectos dos seres humanos — fisiologia, anatomia, sentidos, hábitos alimentares, postura ereta, abundância ou não de pêlos, cor da pele etc. - , mas, quando trata da religião, da linguagem, da escrita, da arte, dos sistemas de parentesco e temas correlatos, afirma que prevalece o 'dedo' da evolução cultural.

Ehrlich pretende destacar "as naturezas humanas, os comportamentos e até as atitudes diversificadas e evolutivas do Homo sapiens e as estruturas físicas evoluídas que comandam, apóiam e participam de nosso peculiar funcionamento mental". O uso do plural em 'naturezas humanas' não é casual — faz parte da estratégia do autor para ressaltar as conseqüências diversificadoras e plurais da convivência entre as duas linhas de evolução, a biológica e a cultural. A conseqüência dessa convivência é uma pluralidade de naturezas humanas. Isso vai frontalmente contra o argumento básico dos geneticistas do comportamento, que defendem a posição de que a cada comportamento corresponde um gene e que, assim, o primeiro é sujeito aos mesmos processos seletivos que embaralham, confirmam ou dissolvem os genes, conforme a sua maior ou menor contribuição para o sucesso reprodutivo. Ao assumir essa posição, Ehrlich diz que os humanos são filhos tanto da natureza (nature) quanto da cultura (nurture), em doses variadas de acordo com as diferentes dimensões do comportamento humano.

Ehrlich escreveu esse livro para oferecer "um antídoto formulado por um evolucionista ao determinismo extremo da hereditariedade genética que infesta grande parte das discussões sobre o comportamento humano - o conceito de que somos de alguma forma prisioneiros de entidades mínimas, auto-replicantes chamadas genes". No entanto, não hesita em apontar que importantes partes do corpo, do cérebro e das formas de cognição dos humanos provavelmente resultam de processos evolutivos genéticos.

Tomemos como exemplo a linguagem falada (tratada principalmente no capítulo 7). Não existem registros precisos de quando, onde e como os hominídeos desenvolveram a capacidade da fala que levou à construção de milhares de linguagens e sistemas simbólicos complexos, o que nenhum outro ser conseguiu realizar. Não se pode afirmar, portanto, que a linguagem seja resultado das vantagens reprodutivas diferenciais, derivadas por uma evolução biológica dedutível a partir dos restos humanos fósseis, tal como, por exemplo, a postura ereta e a oposição do polegar aos demais dedos da mão. É verdade que todas as muitas línguas conhecidas têm três componentes comuns - vocabulário, sintaxe e significado mas existem ritmos de enunciação, ordenamentos de palavras e tons que diferenciam a mesma série de vocábulos dentro da mesma cultura e do mesmo momento histórico. Além do mais, a grande quantidade de línguas conhecidas prova a sua ampla autonomia em relação às determinações puramente genéticas.

No entanto, o autor, jogando água fria nos proponentes da autonomia da cultura, destaca que essa mesma linguagem falada, tão característica 
da cultura humana, tem suporte físico em certos aspectos anatômicos e funcionais da laringe, das cordas vocais e da glote, e em alguns setores 'nobres' do cérebro, todos os quais sujeitos às regras que comandam a evolução do restante do corpo humano. Assim, a conquista essencialmente 'cognitiva' da linguagem falada, um dos fundamentos da abissal distância entre os humanos e os demais animais, é vista simultaneamente como um resultado 'nobre' da evolução cultural e da evolução genética/orgânica do aparelho fonético e do cérebro. Este é um bom exemplo da posição de 'meio-termo' assumida por Ehrlich quanto às diferenças e continuidades entre a cultura e a natureza.

Aliás, é na estrutura e no funcionamento do cérebro humano (ver o capítulo 6) que Ehrlich encontra a base mais forte para a sua argumentação contra o determinismo genético do comportamento. Ele se reporta repetidamente ao fato de haver uma 'escassez de genes' (gene shortage) nos humanos. Ou seja, os cerca de cem mil genes da constituição humana seriam incapazes de controlar os trilhões de sinapses resultantes das interações que ocorrem na rica malha de neurônios que compõem o cérebro e os demais tecidos nervosos. O estado atual da ciência genética aponta para a elevadíssima improbabilidade de que tão poucos genes consigam exercer um controle férreo sobre a enorme totalidade das percepções e comportamentos possíveis para os seres humanos. O erro dos geneticistas do comportamento, segundo Ehrlich, é precisamente atribuir aos nossos genes funções controladoras demasiadamente complexas, capazes de produzir comportamentos padronizados e que, no limite, seriam facilmente previsíveis e até programáveis. Para Ehrlich, o verdadeiro 'filtro' ou 'complicador' dos comportamentos humanos é a cultura, que cria preferências, regras, 'cegueiras' e recorrências — mas, também, as imprevisibilidades - características dos seres humanos.

Vejamos mais um exemplo das argumentações de meio-termo de Ehrlich. Envolve a questão que mais o preocupa como cientista e cidadão - a consciência dos seres humanos quanto à crise ambiental planetária. No capítulo 13, Ehrlich trata de uma particular 'ressaca evolutiva' (evolutionary hangover) - nome curioso que dá a características físicas e comportamentais que perdem valor adaptativo em face de mudanças aceleradas no ambiente e na cultura. Para ele, a formação das sociedades urbano-industriais de massa fez com que "a valorização do ambiente natural se tornasse menos disseminada entre os grupos sociais do que na época em que os indivíduos eram caçadores-coletores ou agricultores de subsistência. ... a maioria dos Homo sapiens urbanizados não dá valor aos serviços prestados pelos ecossistemas".

Isso ocorre em função de uma dissonância cognitiva ligada à evolucão cultural, que condicionou o Homo sapiens a prestar mais atenção às mudanças naturais bruscas e localizadas, e a reagir a elas para sobreviver ou para viver melhor. Por isso ele não aprendeu a atentar para processos lentos e generalizados de mudança natural, exatamente os que causam os grandes problemas ambientais que hoje afligem o planeta - como extinções de espécies, mudanças climáticas, perdas de diversidade genética, contaminação da atmosfera etc. Mesmo que a ciência moderna consiga identificar essas mudanças lentas e de grande amplitude e saiba explicar as suas conseqüências, o público em geral está, segundo Erhlich, culturalmente condicionado a ignorar tais mudanças. 
Para um cientista evolucionista até hoje chamado de alarmista ou catastrofista, essa é uma explicação quase conveniente para a duradoura e generalizada indiferença da maioria das pessoas em relação às constatações ou previsões de desastres ambientais. Mas o ponto mais importante a destacar é que a aplicação da teoria evolucionista ao universo da cultura pode levar à constatação de que certos comportamentos são contraproducentes à sobrevivência ou à prosperidade humanas. Assim, afirmar que certo comportamento resulta da evolução nada diz sobre ele ser 'bom' ou 'mau', ao contrário do que afirmam ou denunciam os que pouco leram sobre evolucionismo. Mesmo no campo do evolucionismo biológico, aquilo que é evoluído não é em qualquer sentido 'melhor'. O que resulta da evolução não é de maneira alguma o que 'deve' acontecer. Mais sinteticamente ainda, não há 'mensagem normativa' naquilo que resulta da evolução. Este é um importante recado do evolucionista Ehrlich, ilustrado por dezenas de maneiras ao longo do texto e prenhe de implicações éticas e filosóficas.

É difícil dar uma idéia do conjunto de assuntos tratados, nesse livro, por Eherlich à luz do evolucionismo — anatomia, fisiologia, hábitos, agricultura, pecuária, pesticidas, genoma, genótipos e fenótipos, emoções, doenças, altruísmo, educação, dietas, parentesco, guerra, genocídio etc. Aliás, é difícil até definir o seu gênero. A diversidade de temas indica que não é uma monografia didática ou científica. Trata-se por certo de um esforço de divulgação científica, mas Ehrlich se afasta do gênero por tratar de dezenas de linhas de pesquisa desconectadas entre si, desenvolvidas em muitas disciplinas e por cientistas de muitas instituições e países. Não é um livro-texto que sirva como leitura de fundo para algum programa de estudo, mesmo interdisciplinar. Talvez a melhor definição seja temática: é um tratado científico de como o evolucionismo se aplica (ou não) a muitas dimensões dos seres humanos. Define-se ainda como uma longa e minuciosa denúncia dos abusos cometidos pelos adeptos da genética comportamental (ou da sociobiologia vulgar) em voga. É um livro único, mesmo dentro da alentada produção do autor.

As 89 páginas de notas (por vezes enriquecidas com interessantes comentários) contêm um verdadeiro tesouro de referências aos principais livros e artigos que registram os achados das múltiplas linhas de pesquisa examinadas por Ehrlich. Em geral, ele cita primeiro os clássicos referentes a cada tema, chegando até a literatura mais recente e as pesquisas em curso. Em vários casos, usa um recurso incomum: agrega, às notas, informações recentes obtidas através de contatos pessoais com os principais pesquisadores de cada tema. As quase trinta páginas do índice remissivo permitem que se use o livro também como obra de consulta a respeito de temas, linhas de pesquisa e pesquisadores.

É um livro instigante, erudito, relativamente fácil de ler (todos os termos ou jargões científicos são explicados no próprio texto), tendo em vista a diversidade temática e o caráter relativamente avançado de muitas discussões. Apesar disso, Ehrlich nunca perde o foco do seu assunto principal - a aplicabilidade da teoria evolucionista ao estudo do comportamento humano. Essa produção de Ehrlich guarda um certo parentesco com os livros mais recentes de Stephen J. Gould e de Jared Diamond (mais conhecidos pelos leitores brasileiros), pois todos são 
cientistas naturais que se aventuram pelo universo temático das ciências humanas e sociais, além de se filiarem a uma ou outra vertente do evolucionismo darwiniano. Enfim, recomendo a leitura desse livro para quem se dispuser a testar as suas convicções favoráveis ou contrárias ao evolucionismo e para todos os que se interessam pela situação passada, atual e futura desse animal especial que é o Homo sapiens.

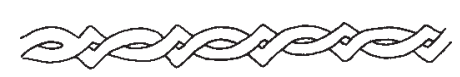


䢺 